\title{
The progressive effect of the individualistic response of species to Quaternary climate change: an analysis of British mammalian faunas
}

\author{
John R. Stewart* \\ Department of Palaeontology, The Natural History Museum, Cromwell Road, London SW7 5BD, UK.
}

\section{A R T I C L E I N F O}

\section{Article history:}

Received 30 May 2008

Received in revised form 8 August 2008

Accepted 8 August 2008

\begin{abstract}
A B S T R A C T
The individualistic response of species to climate change is accepted by many although how this process works across several climate oscillations has not been widely considered. A cluster analysis using the Bray-Curtis metric with single linkage to show relative faunal similarity was performed on successively older British mammalian faunas to investigate whether they become progressively different compared to the present day (Holocene). British mammalian faunas from MIS 3, 5, 11, 13 and 17 were compared with the Holocene revealing that the last glaciation (MIS 3) is more different than are any of the interglacials (MIS 5, 11, 13, 17). Furthermore, the interglacials generally become more distinct from the Holocene with age. This difference relates to the fact that interglacial faunas have greater proportions of extinct and extirpated species with increased age. The increase in extirpated taxa in turn relates to faunas becoming more non-analogue with greater age. The increase in extirpated elements with age probably relates to the individualistic response to climate change which appears to be progressing with time. The implications of this progressive process are considered in relation to refugia, extinction and evolution.
\end{abstract}

(C) 2008 Elsevier Ltd. All rights reserved.

\section{Introduction}

It is widely accepted that species, and not ecological communities, respond to climate change. This has become known as the individualistic, or Gleasonian (Gleason, 1926), response to climate change (Graham, 1985a, b; Faunmap Working Group, 1996; Jablonski and Sepkoski, 1996; Williams et al., 2001; Williams and Jackson, 2007) and is the counterpart to the Clementsian (Clements, 1904), community response. It is also believed by many that the individualistic response lies behind the phenomenon whereby ecological communities in the Quaternary are often composed of taxa that today have allopatric distributions (Graham, 1985a; Huntley, 1991; Roy et al., 1995; Jablonski and Sepkoski, 1996; Williams et al., 2001). Indeed such non-analogue communities have been widely documented amongst almost the complete spectrum of organisms with Quaternary fossil records. Examples are known amongst both vascular plants (Bell, 1969; Huntley, 1990, 1991; Kullman, 1998, 2002; Williams et al., 2001) and diatoms (Gasse et al., 1997). In animals, examples include birds (Bramwell, 1984; Emslie, 1986; Brasso and Emslie, 2006), beetles (Coope and Angus, 1975; Coope, 2000), terrestrial molluscs (Kerney, 1963; Preece and Bridgland, 1998), marine molluscs (Roy et al., 1995), foraminifera (Whittaker in Bates et al., 2000), polychaetes (Sanfilippo, 1998),

\footnotetext{
* Tel.: +44 2079425398.

E-mail address: s.john@nhm.ac.uk
}

dinoflagellates (Head, 1998) and mammals (Graham, 1985a, b; Graham and Grimm, 1990; Guthrie,1990a,b; Faunmap Working Group, 1996; Stafford et al., 1999; Tankersley, 1999; Stewart et al., 2003; Stewart, 2005). Different explanations for non-analogue communities have been offered by various authors (Kerney, 1963; Bramwell, 1984, Graham and Grimm, 1990; Faunmap Working Group, 1996; Stafford et al., 1999) although the main alternative explanation for non-analogue assemblages is that they are mixtures of fossil taxa of different ages. For example, the nonanalogue coleopteran assemblages from the Late Pleistocene have been explained as a mixture of material dating from distinct intervals with different climates during the Late Pleistocene (Coope, 2000). Mammalian researchers have however successfully proved the contemporaneity of species not expected in sympatry by using AMS ${ }^{14} \mathrm{C}$ dating (Stafford et al., 1999).

The individualistic response of species has long been used to explain the different vegetational elements that recombine during the successive climatic episodes of the Quaternary (West, 1980; Webb, 1986; Prentice, 1986). Phylogeographers have also recognised the same polarised hypotheses and have called these the concerted (community) versus independent (individual species) responses to environmental fluctuations (Sullivan et al., 2000). Taberlet et al. (1998) in their paper on comparative phylogeography in Europe give firm support to the individualistic response of species.

Furthermore, the individualistic response of species over several climatic cycles is likely to lead to a progressive effect. With 
increasing age there should be an increase in the degree to which ecologies deviate from modern analogues. This effect has been demonstrated by the ever changing composition of biotas though time (Hengeveld, 1994). A similar ecological phenomenon has been recognised for some time, in the increasing proportion of extinct to extant species that occur through time (e.g. Harmer, 1900a, b; Jablonski and Sepkoski, 1996). This paper presents an analysis of the degree to which mammalian species in Britain can be shown to respond individualistically to climate change in a progressive way. The ecological and evolutionary implications of this progressive individualistic response are then explored.

\section{Materials and methods}

To test the hypothesis that ecologies in the past were progressively less analogous to those of the Holocene with increasing age, an analysis was conducted on the mammalian faunas of Britain (in practise England and Wales) during the last 700,000 years.

The faunas of Britain are relatively well known and the data used in this analysis is from six progressively older faunas. An area the size of Britain is considered here to be large enough to contain a degree of regional ecological diversity without crossing climatic boundaries and faunal provinces. The youngest fauna analysed was that which existed in Britain during the Holocene (10,000 yearspresent) and is here considered to be the "natural" present day fauna. It is the Holocene fauna that is used here as the analogue with which older faunas are compared. The fauna is essentially the present day British species list although it includes taxa now locally extinct (extirpated) in Britain such as wolf Canis lupus, wild boar Sus scrofa, brown bear Ursus arctos and beaver Castor fiber, which have disappeared due largely to anthropogenic reasons (Stuart, 1995). Conversely, it also excludes the species that have been introduced by humans including grey squirrel Sciurus carolinensis, fallow deer Dama dama, brown hare Lepus europaeus and rabbit Oryctolagus cuniculus (Lever, 1977; Yalden, 1999). It was recently claimed that harvest mouse Micromys minutus and birch mouse Sicista are extinct Holocene natives to Britain (Kitchener and Yalden, 2008) although they have been omitted here due to concerns over the reliability of their ages. New claims, such as these, need to be verified, ideally with radiocarbon dates on the remains themselves, to remove the possibility that stratigraphic mixing is involved. Another perspective of the Holocene fauna in the present analysis is that certain taxa like the hedgehog and squirrel have been described as Erinaceus sp. and Sciurus sp. respectively. This is because the Pleistocene fossil records of these two taxa have not been identified to species. This in turn signifies that if the full species names for the Holocene records (i.e. E. europaeus and S. vulgarius) are used in the analysis it might artificially enhance the difference between the Holocene and older faunas with those taxa.

The analysis presented here is restricted to faunas whose ages are conservatively reliable. Therefore, faunas that are likely to date to MIS 7 (Marine Isotope Stage 7) and 9 are omitted because their ages are determined using the mammalian faunal compositions of the relevant sites (biostratigraphy) (Schreve, 2001) and to use these same compositions in this analysis would be circular.

The first fauna with which the Holocene is compared is that from MIS 3, the period between 60 and 25 thousand radiocarbon years before present (BP). These MIS 3 faunas derive from a number of sites which have a degree of reliability as to age based on associated ${ }^{14} \mathrm{C}$ dating and formed part of the Stage 3 Project database (Stewart et al., 2001). [The dates for some of the MIS 3 faunas included here have been questioned recently (Gilmour et al., 2007) although it is felt that all the taxa taken here as being found in Britain during MIS 3 (Appendix) were genuinely present. The distinctions seen by Gilmour et al. (2007) are in the dominance of specific taxa rather than in presence versus absence.]
The rest of the faunas analysed are believed to be from the peaks of interglacials. The next oldest fauna, from MIS 5e (the last interglacial), comes from a number of sites whose taxa are listed by Stuart (1995) (Shropham and Swanton Morley, Norfolk; Barrington, Cambridgeshire; Joint Mitnor, Devon; Victoria Cave, Yorkshire). They are relatively well dated and have a uranium series date of around 120,000 years from Victoria Cave in Yorkshire (Gascoyne et al., 1981). The other four MIS 5e sites are traditionally correlated with the Victoria Cave date by their faunas, which are often called the "hippopotamus fauna", as they appear to be the only later Pleistocene faunas with hippos and a relative lack of extinct taxa in Britain. MIS 11 (an earlier interglacial) has been represented by three sites whose ages can be reasonably correlated because two independent sources of age exist. They are the Lower Loam and Lower Gravels at Swanscombe in Kent, and Beeches Pit and Barnham in Suffolk. Their similar age is suggested by their distinctive molluscan fauna and associated amino acid racemisation dates (Preece et al., 2000, 2007). Their faunas are described by Parfitt (1998) and Preece et al. (2007). The inclusion of Swanscombe on the one hand, and Beeches Pit and Barnham on the other, allows for a better consideration of both large and small mammals respectively.

Boxgrove is the next oldest fauna in the analysis, and is believed by many to represent MIS 13 , giving it an age of approximately 500,000 years old (Parfitt, 1999). The site has been extensively excavated over several years and has one of the richest faunas in the British Pleistocene, including Britain's oldest human remains (Roberts and Parfitt, 1999). Finally, West Runton is used which falls in an earlier part of the Cromerian Complex and has recently been correlated with MIS 17 (Maul and Parfitt, in press). The data for West Runton has been taken from Maul and Parfitt (in press), Preece and Parfitt (2000) and Stuart (1995). The use of individual sites in the analysis as achieved here with Boxgrove and West Runton used to represent MIS 13 and 17 respectively can circumvent the problems of potentially lumping sites of different ages under a single age category. The latter can only happen if sites exist with extensive faunas resulting from significant ongoing collection campaigns of both large and small mammals.

In an analysis of similarity of the fauna it is possible that factors influence the difference in their composition other than increased age. The taphonomic origin of a fauna is perhaps the most important confounding factor here. This has guided the choice of sites and hence where possible sites with the same taphonomic origins were used in the analysis. For example faunal assemblages from cave sites usually have a different taphonomic history to those from open air sites. In caves the origins of the faunal material is often from predator accumulations, whether it be owls depositing small mammals or hyaenas and wolves accumulating larger mammals. In open air sites, on the other hand, a broader range of processes are often involved with relative resistance to mechanical erosion and weathering and speed of burial often dominating the resultant assemblage composition. It is also imperative that the sites in question have been sieved adequately to promote the recovery of small mammals. The three oldest faunas (MIS 11, 13 and 17) have received significant attention in this regard and are all open air sites with reasonable small mammal lists. The MIS 5e and 3 faunas are based on more sites which is partly to acknowledge the fact that sieving appears to have been less systematic and partly to overcome the greater number of the site types as both faunas include cave and open sites. It is hoped that inclusion of open air sites will counter the ecological effect of the cave sites among both the MIS 5e and MIS 3 sites. The faunas used in the analysis include the best available sites and short of further field work the potential biases above can only be acknowledged.

Another factor which could be partially affecting the composition of British mammalian faunas is the variable island to peninsular status of the area (e.g. Stuart, 1995). While this clearly plays 
a role it can be considered to be part of the individualistic response as different taxa are likely to move to Britain at different rates relative to the area becoming isolated.

The presence/absence of mammalian taxa from the above age categories is shown in the Appendix. A cluster analysis using the Bray-Curtis metric with single linkage was conducted on this data using BioDiversity Pro software package and the results of this analysis are shown in a tree (Fig. 1). The Bray-Curtis metric allows the analyses of taxonomic datasets to establish ecological distance and is often used to do so with palaeoecological datasets (e.g. Park and Downing, 2001). In addition to the tree the percentage pair wise similarity values to (the Holocene fauna) are presented in Table 1 . This analysis was performed using the faunas expressed as species (Appendix 1) present through time (Table 1). Also shown in Table 1 is the percentage of extinct, extant and extirpated taxa. Finally, in order to graphically demonstrate the decreasing degree of similarity values with time the percentage pair wise similarity, using the Bray-Curtis metric (to the Holocene fauna), for species were plotted against the approximate ages of each fauna (Fig. 2).

\section{Results of analysis of progressive independence}

The Bray-Curtis cluster analysis reveals (Fig. 1) that the past interglacials are all more different from the Holocene than they are from each other. Therefore, the tree in Fig. 1 shows the Holocene fauna forming a sister group to all the interglacial faunas (MIS 5e, 11, 13, 17). In addition, the past interglacials generally become progressively more distinct from each other as they get older as indicated by their percentage Bray-Curtis similarity indices (Table 1 , Fig. 2). The exception is that the fauna from MIS 13 is more similar to that of the Holocene than is that from the younger MIS 11. This may be partly due to sampling because MIS 13 has a larger faunal list, with 46 species, than MIS 11, with 39 species. The larger faunal list has contributed to the greater number of taxa in MIS 13 that are still present in Britain (Table 2). They include the hedgehog Erinaceus sp., the mole Talpa europaea, the mountain hare Lepus timidus, the hazel dormouse Muscardinus avellanarius, the weasel and/or stoat Mustela nivalis/M. erminea and the badger Meles meles.

The glacial fauna of MIS 3 does not follow the progressive difference and falls outside the cluster that includes all the interglacial faunas (Fig. 1). This suggests that glacial faunas are probably generally more different from interglacial ones than interglacials are from each other. Table1 helps explain the tree in Fig. 1, showing the British mammalian faunas from progressively older time

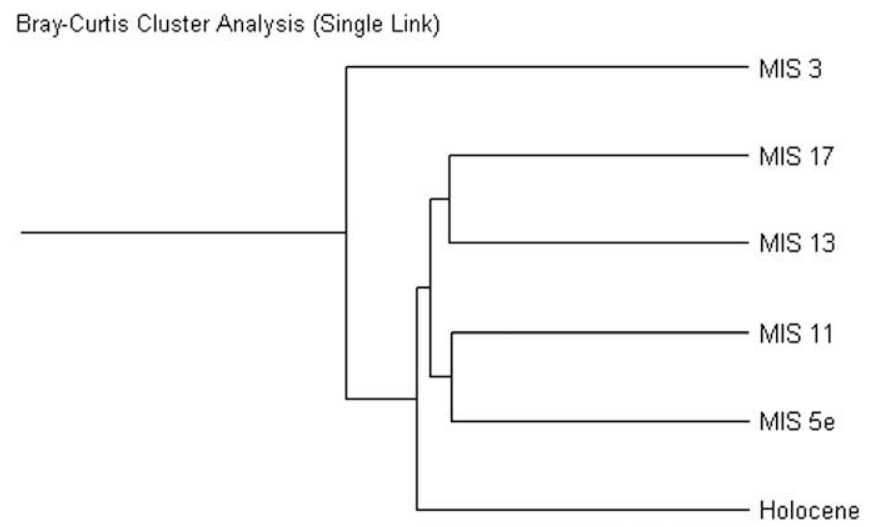

0. \% Similarity

Fig. 1. Bray-Curtis cluster analysis of British faunas from the Holocene, former interglacials (MIS 5e, 11, 13 and, 17) and part of the Last Glacial (MIS 3). episodes broken down into the percentage extant, extinct and extirpated as well as the percentage pair-wise similarity values to the Holocene fauna. This analysis confirms that there is a progressive change in the mammalian fauna of the British Isles. Therefore, the fauna from MIS 5e is more similar to that of the Holocene in terms of both extinct and extirpated taxa than is the fauna from MIS 11. This change appears to be due to both an increase in extinct and extirpated (locally extinct) species with a corresponding decrease in extant taxa. However, while the percentage of extinct taxa increases with each older interglacial, the percentage of extirpated taxa increases and then greatly decreases between MIS 13 and MIS 17. The decrease in extirpated species between MIS 13 and 17 may be due to a threshold which is reached whereby morphological differences are no longer considered subspecific locally extinct populations and instead require classifying as extinct species. Regardless of this, it is clear that there is an increase in difference with increasing age of British interglacial faunas and the Last Glacial (MIS 3) fauna is particularly different in terms of extirpated taxa. This implies a great deal of faunal change that involves distribution change of an individualistic nature.

The analysis was also performed on the data after removing the extinct taxa from the presence/absence matrix of the different faunas (Appendix). The result of this is to produce a significantly less steep trend into the past demonstrating the importance of the influence of the extinct taxa in the analysis. There is, however, a trend, among the interglacial faunas, of decreasing similarity to that from the Holocene, with increasing age. The most realistic analysis result is probably somewhere between the results of the two analyses, with and without extinct taxa, because a significant proportion of the extinct interglacial taxa are phylogenetically ancestral, or closely related, to extant taxa. Therefore, it is more reasonable to consider the results including the extinct taxa.

\section{Discussion-consequence of progressive individualistic response}

The progressive individualistic response of species through time has been demonstrated here for mammals in Britain although it seems likely that this process exists in other organisms in the Quaternary. Certainly, Hengeveld (1994) suggests as much in a review of the state of biogeographical ecology: "local community ecology composition deviate from a particular one, the greater the distance both in time-non-analogue vegetations-and space". It is also implied by many other studies even if it is not described as such. For example much of the work done by palynologists in Europe and elsewhere have this phenomenon at their core (e.g. Tzedakis and Bennett, 1996). It also lay behind the use of palynology as a relative dating method (e.g. West, 1970) although the use of pollen spectra in age determination has been criticised, certainly in Britain, due to demonstrations that comparable pollen spectra can occur during separate interglacials (Sutcliffe and Kowalski, 1976). The latter could indicate that the individualistic response of plant taxa to climate change may not always result in progressively different floras although there are problems with the interpretation of pollen in reconstructing plant migration rates (Reid's Paradox-Clark et al, 1998). More recently a similar biostratigraphic use has been made of mammals in Britain (Schreve, 2001). Here again the different interglacials are characterised as having similar but distinct faunas. These uses of biological remains in biostratigraphy both rely on the ever changing combinations of taxa which in turn are presumably formed by the individualistic response of species. Non-analogue communities are the most extreme manifestation of such re-combinations.

The fact that these re-combinations occur has implications for other phenomena and processes in the population biology of organisms through time and space. These shall be discussed in turn. 
Table 1

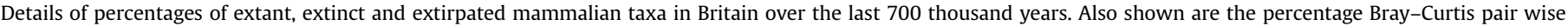
similarities to the Holocene mammalian faunas of progressively older faunas

\begin{tabular}{|c|c|c|c|c|c|c|}
\hline & \multirow{2}{*}{$\begin{array}{l}\text { Interglacial } \\
\text { Holocene } \\
(0-10 \mathrm{Ka})\end{array}$} & \multirow{2}{*}{$\begin{array}{l}\text { Glacial } \\
\text { MIS } 3 \\
(60-25 \mathrm{Ka})\end{array}$} & \multicolumn{4}{|l|}{ Interglacials } \\
\hline & & & $\begin{array}{l}\text { MIS 5e } \\
(\text { ca } 120 \mathrm{Ka})\end{array}$ & $\begin{array}{l}\text { MIS } 11 \\
(\text { ca } 400 \mathrm{Ka})\end{array}$ & $\begin{array}{l}\text { MIS } 13 \\
(\text { ca } 500 \mathrm{Ka})\end{array}$ & MIS 17 (ca $700 \mathrm{Ka})$ \\
\hline Total no. of species & 30 & 33 & 25 & 39 & 46 & 42 \\
\hline Percentage extant in Britain (No. extant) & $100(30)$ & $42.42(14)$ & $60(15)$ & $38.46(15)$ & $36.96(17)$ & $33.33(14)$ \\
\hline Percentage extinct (No. extinct) & 0 & $18.18(6)$ & $16(4)$ & $30.77(12)$ & $32.61(15)$ & $45.24(19)$ \\
\hline Percentage extirpated in Britain (No. extirpated) & 0 & $39.39(13)$ & $24(6)$ & $30.77(12)$ & $30.43(14)$ & $21.42(9)$ \\
\hline Percentage Bray-Curtis similarity to Holocene (Species) & - & 44.44 & 54.55 & 43.48 & 44.74 & 38.36 \\
\hline $\begin{array}{l}\text { Percentage Bray-Curtis similarity to Holocene (Species) } \\
\text { excluding the extinct taxa }\end{array}$ & - & 49.12 & 58.82 & 52.63 & 55.74 & 52.83 \\
\hline
\end{tabular}

\subsection{Refugia}

Refugia exist when species are in the contraction phase of their populations. Unlike extinctions, however, refugial populations are viable and can subsequently expand when optimal conditions broaden again. The individualistic response of species implies that refugia for different species need not coincide completely in area or time. If they do it is because the physical conditions required for the species exist and not because of the presence of other apparently similar ecological species (Smith and Smith, 1998). The progressive nature of the individualistic response further implies that refugia for a given species are likely to vary with the climate space that exists at any one time. Certain areas may re-occur as refugia in subsequent, similar climates although this is mostly dictated by the climates themselves and to a lesser extent on variations in land areas and topography.

The clearest example of the effect of the individualistic response to climate change is the difference between species found today in cold northern areas when compared to those from more southern temperate parts of the Palaearctic and Nearctic. Temperate species respond by contracting southwards and/or into cryptic northern refugia during glaciations (Hewitt, 1996, 2000, 2001; Taberlet et al, 1998; Stewart and Lister, 2001). Northern species, however, are generally in their expansive phases in cold stages and in refugia during interglacials such as that today (Stewart and Lister, 2001; Dalén et al., 2005; Stewart and Dalén, 2008). Various authors working on the phylogeography of a number of arctic taxa (Tremblay and Schoen, 1999; Holder et al., 1999; Fedorov and Stenseth, 2002; Loehr et al., 2005; Pruett and Winker, 2005; Anderson et al., 2006) have suggested that such taxa are in a population contraction phase during glacials. While this may be true for the glacial maxima, it is not the case for the whole glacials, as these are the times during which such species are generally in their expansive phases (Mourer-Chauviré, 1979; Musil, 1985; Tyrberg, 1991, 1995; Markova et al., 2002; Stewart, 1999; Stewart et al., 2003). The glacial refugium concept should therefore be complemented by an interglacial equivalent (see Bennett and Provan, 2008). It is also clear

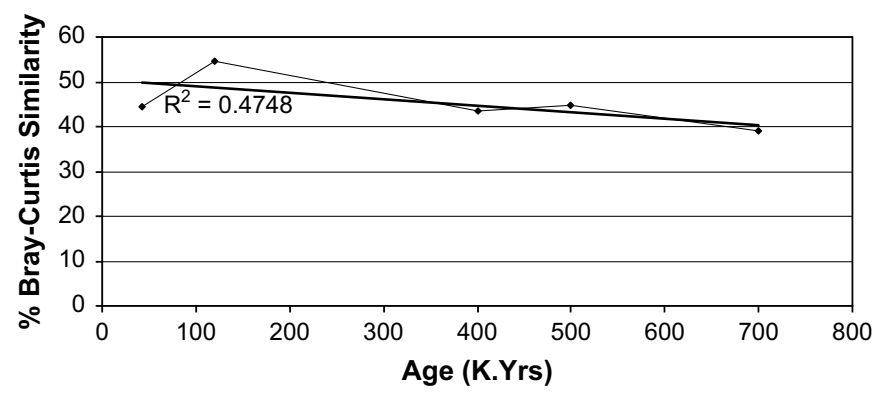

Fig. 2. Percentage Bray-Curtis similarity to the Holocene mammalian fauna of progressively older faunas plotted against their estimated ages. Also shown is trend line with $\mathrm{R}^{2}$ value derived from all similarity indices. that taxa whose ecological and climatic adaptations appear to be defined by continental versus oceanic characteristics will need to be considered separately.

\subsection{Extinction}

The subject of extinction (whether extinction of populations or species) is related to that of refugia as both involve the contraction phase of species. In extinctions the contraction phase of species (or populations) is complete while in refugia small remnants of a population survive.

The relationship between non-analogue communities, and by analogy the individualistic response, and extinction has been described by various authors. These authors suggest that the disappearance of "disharmonious" communities at the same time as the megafaunal extinctions, including that of the Neanderthals, indicates that climate, rather than modern human predation or competition, is the main cause their demise (Graham and Lundelius 1984; Guthrie, 1990a; Stewart, 2005). This is because the loss of large mammals of the Late Pleistocene were simply considered to be part of a 'faunal revolution' involving many changes including the major reorganisations of ecological communities (Guthrie, 1990a; Faunmap, 1996). This point of view was rejected by Alroy (1999) who criticised the link that has been made between the megafaunal extinctions of the Late Pleistocene and the loss of nonanalogue assemblages. He argued that such non-analogues are very rare and were not restricted to the Pleistocene. He did acknowledge (Alroy, 1999) that differences between glacial and interglacial faunas had been noted and attributed these to differences in seasonal climates (e.g. Graham, 1986) and suggested that this partly lay behind the non-analogue phenomenon. However, he asserted that most mammals "maintained ecologically stable and predictable distribution that only gradually contracted in the face of Holocene environmental change" (Alroy, 1999). Graham (2006) vigorously rejected Alroy's stance on non-analogue communities suggesting that Alroy used a non-traditional definition of nonanalogues which artificially decreased the number of observed examples of such biotas.

It is clear, however, that the individualistic response implies that we should not expect species extinctions to be completely synchronous or, for the last populations of species, to be in precisely the same place. Also, the progressive nature of the individualistic response may suggest a further level of complexity to the extinction process as populations are likely to go extinct or become locally adapted in an unpredictable, stochastic way. The progressive individualistic phenomenon only affects species at a population level through time because once the species is extinct it can no longer respond, differently or otherwise. Populations are likely to have responded differently, according to the species involved, which is a predictable outcome of the progressive individualistic response. It is also likely that different populations of a single species could respond differently to the same environmental change. 
Table 2

Extant, extinct and extirpated mammalian taxa in Britain over the last 700 thousand years

\begin{tabular}{|c|c|c|c|c|c|c|}
\hline & \multirow{2}{*}{$\begin{array}{l}\text { Interglacial } \\
\text { Holocene } \\
(0-10 \mathrm{Ka})\end{array}$} & \multirow{2}{*}{$\begin{array}{l}\text { Glacial } \\
\text { MIS } 3 \\
(60-25 \mathrm{Ka})\end{array}$} & \multicolumn{4}{|l|}{ Interglacials } \\
\hline & & & $\begin{array}{l}\text { MIS 5e } \\
\text { (ca } 120 \mathrm{Ka})\end{array}$ & $\begin{array}{l}\text { MIS } 11 \\
\text { (ca } 400 \mathrm{Ka})\end{array}$ & $\begin{array}{l}\text { MIS } 13 \\
(\text { ca } 500 \mathrm{Ka})\end{array}$ & $\begin{array}{l}\text { MIS } 17 \\
(\text { ca } 700 \mathrm{Ka})\end{array}$ \\
\hline $\begin{array}{l}\text { Total no. } \\
\text { of species }\end{array}$ & 30 & 33 & 25 & 39 & 46 & 43 \\
\hline Extant & $\begin{array}{l}\text { Erinaceus sp. } \\
\text { Sorex araneus } \\
\text { Sorex minutus } \\
\text { Neomys fodiens } \\
\text { Talpa europaea } \\
\text { Homo sapiens } \\
\text { Lepus timidus } \\
\text { Sciurus sp. } \\
\text { Castor fiber } \\
\text { Clethrionomys } \\
\text { glareolus } \\
\text { Arvicola t. terrestris } \\
\text { Microtus agrestis } \\
\text { Apodemus flavicollis } \\
\text { Apodemus sylvaticus } \\
\text { Muscardinus } \\
\text { avellanarius } \\
\text { Canis lupus } \\
\text { Vulpes vulpes } \\
\text { Ursus arctos } \\
\text { Mustela nivalis/ } \\
\text { erminea } \\
\text { Mustela putorius } \\
\text { Meles meles } \\
\text { Martes martes } \\
\text { Lutra lutra } \\
\text { Felis sylvestris } \\
\text { Lynx lynx } \\
\text { Sus scrofa } \\
\text { Cervus elaphus } \\
\text { Capreolus capreolus } \\
\text { Alces alces } \\
\text { Bos primigenius }\end{array}$ & $\begin{array}{l}\text { Neomys fodiens } \\
\text { Homo sapiens } \\
\text { Lepus timidus } \\
\text { Arvicola t. terrestris } \\
\text { M. agrestis } \\
\text { Canis lupus } \\
\text { Vulpes vulpes } \\
\text { Ursus arctos } \\
\text { Mustela nivalis /erminea } \\
\text { Mustela putorius } \\
\text { Felis sylvestris } \\
\text { Cervus elaphus } \\
\text { Alces alces } \\
\text { Bos primigenius }\end{array}$ & $\begin{array}{l}\text { Sorex araneus } \\
\text { Sorex minutus } \\
\text { Neomys fodiens } \\
\text { Castor fiber } \\
\text { Clethrionomys glareolus } \\
\text { Microtus agrestis } \\
\text { Apodemus sylvaticus } \\
\text { Canis lupus } \\
\text { Vulpes vulpes } \\
\text { Ursus arctos } \\
\\
\text { Meles meles } \\
\text { Felis sylvestris } \\
\text { Sus scrofa } \\
\text { Cervus elaphus } \\
\text { Bos primigenius }\end{array}$ & $\begin{array}{l}\text { Sorex minutus } \\
\text { Neomys fodiens } \\
\text { Sciurus sp. } \\
\text { Castor fiber } \\
\text { Clethrionomys glareolus } \\
\text { Microtus agrestis } \\
\text { Apodemus sylvaticus } \\
\text { Canis lupus } \\
\text { Mustela putorius } \\
\text { Martes martes } \\
\text { Felis sylvestris } \\
\text { Sus scrofa } \\
\text { Cervus elaphus } \\
\text { Capreolus capreolus } \\
\text { Bos primigenius }\end{array}$ & $\begin{array}{l}\text { Erinaceus sp. } \\
\text { Sorex minutus } \\
\text { Neomys fodiens } \\
\text { Talpa europaea } \\
\text { Lepus timidus } \\
\text { Sciurus vulgaris } \\
\text { Castor fiber } \\
\text { Clethrionomys glareolus } \\
\text { Microtus agrestis } \\
\text { Apodemus sylvaticus } \\
\text { Muscardinus avellanarius } \\
\text { Mustela nivalis/erminea } \\
\text { Meles meles } \\
\text { Felis sylvestris } \\
\text { Sus scrofa } \\
\text { Cervus elaphus } \\
\text { Capreolus capreolus }\end{array}$ & $\begin{array}{l}\text { Erinaceus sp. } \\
\text { Sorex minutus } \\
\text { Talpa europaea } \\
\text { Lepus timidus } \\
\text { Castor fiber } \\
\text { Clethrionomys glareolus } \\
\text { Apodemus sylvaticus } \\
\text { Mustela nivalis /erminea } \\
\text { Martes martes } \\
\text { Lutra lutra } \\
\text { Felis sylvestris } \\
\text { Sus scrofa } \\
\text { Cervus elaphus } \\
\text { Capreolus capreolus }\end{array}$ \\
\hline Extinct & & $\begin{array}{l}\text { Homo cf. neanderthalensis } \\
\text { Ursus spelaeus } \\
\text { Mustela putorius robusta } \\
\text { Mammuthus primigenius } \\
\text { Coelodonta antiquitatis } \\
\text { Megaloceros giganteus }\end{array}$ & $\begin{array}{l}\text { Arvicola terrestris cantiana } \\
\text { Palaeoloxodon antiquus } \\
\text { S. hemitoechus } \\
\text { Megaloceros giganteus }\end{array}$ & $\begin{array}{l}\text { Sorex runtonensis } \\
\text { Talpa minor } \\
\text { Homo cf. neanderthalensis } \\
\text { Trogontherium cuvieri } \\
\text { Arvicola t. cantiana } \\
\text { Apodemus maastrichtiensis } \\
\text { Ursus spelaeus } \\
\text { Palaeoloxodon antiquus } \\
\text { Equus hydruntinus } \\
\text { Stephanorhinus hemitoechus } \\
\text { S. kirchbirgensis } \\
\text { Megaloceros giganteus }\end{array}$ & $\begin{array}{l}\text { Sorex runtonensis } \\
\text { Sorex savini } \\
\text { Talpa minor } \\
\text { Homo cf. heidelbergensis } \\
\text { Pliomys episcopalis } \\
\text { Arvicola terrestris cantiana } \\
\text { Apodemus maastrichtiensis } \\
\text { Canis lupus mosbachensis } \\
\text { Ursus deningeri } \\
\text { P. cf. gombaszoegensis } \\
\text { Stephanorhinus sp. A. } \\
\text { S. hundsheimensis } \\
\text { Megaloceros verticornis } \\
\text { Megaloceros dawkinsi } \\
\text { Caprinae }\end{array}$ & $\begin{array}{l}\text { Sorex runtonensis } \\
\text { Sorex savini } \\
\text { Neomys newtoni } \\
\text { Macroneomys } \\
\text { brachygnathus } \\
\text { Talpa minor } \\
\text { Trogontherium cuvieri } \\
\text { Pliomys episcopalis } \\
\text { Mimomys savini } \\
\text { Pitymys gregaloides } \\
\text { Canis lupus } \\
\text { mosbachensis } \\
\text { Ursus deningeri } \\
\text { Pannonictis sp. } \\
\text { P. cf. gombaszoegensis } \\
\text { Mammuthus } \\
\text { trogontherii } \\
\text { S. hundsheimensis } \\
\text { Megaloceros dawkinsi } \\
\text { Megaloceros savini } \\
\text { Alces latifrons } \\
\text { Bison schoentensacki }\end{array}$ \\
\hline Extirpated & & $\begin{array}{l}\text { Ochotona pusilla } \\
\text { Citellus sp. } \\
\text { Dicrostonyx torquatus } \\
\text { Microtus gregalis } \\
\text { Microtus arvalis } \\
\text { Microtus oeconomus } \\
\text { Alopex lagopus } \\
\text { Gulo gulo } \\
\text { Crocuta crocuta } \\
\text { Panthera leo } \\
\text { Equus ferus } \\
\text { Rangifer tarandus } \\
\text { Bison priscus }\end{array}$ & $\begin{array}{l}\text { Microtus oeconomus } \\
\text { Crocuta crocuta } \\
\text { Panthera leo } \\
\text { Hippopotamus amphibius } \\
\text { Dama dama } \\
\text { Bison priscus }\end{array}$ & $\begin{array}{l}\text { Crocidura sp. } \\
\text { Desmana moschata } \\
\text { Macaca sylvanus } \\
\text { Oryctolagus cuniculus } \\
\text { Microtus subterraneus } \\
\text { Microtus arvalis } \\
\text { Microtus oeconomus } \\
\text { Eliomys quercinus } \\
\text { Panthera leo } \\
\text { Equus ferus } \\
\text { Dama dama } \\
\text { Bison priscus }\end{array}$ & $\begin{array}{l}\text { Oryctolagus cuniculus } \\
\text { Myopus schisticolor } \\
\text { Microtus subterraneus } \\
\text { Microtus gregalis } \\
\text { Microtus arvalis } \\
\text { Microtus oeconomus } \\
\text { Sicista cf. betulina } \\
\text { Eliomys quercinus } \\
\text { Mustela lutreola } \\
\text { Crocuta crocuta } \\
\text { Panthera leo } \\
\text { Equus ferus } \\
\text { Dama dama } \\
\text { Bison priscus }\end{array}$ & $\begin{array}{l}\text { Desmana moschata } \\
\text { Macaca sylvanus } \\
\text { Cricetus cricetus } \\
\text { Cricetulus migratorius } \\
\text { Microtus subterraneus } \\
\text { Microtus oeconomus } \\
\text { Crocuta crocuta } \\
\text { Equus ferus } \\
\text { Dama dama }\end{array}$ \\
\hline
\end{tabular}




\subsection{Evolution}

"Perhaps the effects of ice age range changes that are most likely to lead to adaptive novelty and divergence are the different conditions and organisms that a species may meet in its various refugia." (Hewitt, 1996).

The fact that the individualistic response has led to the mixing of biota, and appears to have progressed through time, suggests that evolution is moving at a significant pace in the Quaternary (Hewitt, 1996, 2000). This is because in addition to the evolutionary response of taxa to environmental change there is likely to have been changes to the populations in response to novel interactions between new neighbour species (see above quote). This hypothesis has some support because many populations of animals living in these different combinations are likely to have become extinct as range contractions occurred. The latter are only reliably demonstrated by use of ancient DNA studies such as those pioneered by Barnes et al. (2002). Evidence for extinct populations, living in nonanalogue associations, has been found in the aDNA of arctic fox remains from the lower latitudes of the Late Pleistocene (in North West Europe) (Dalén et al., 2007). These populations have been shown to have become extinct as their ranges contracted at the end of the Pleistocene (Dalén et al., 2007) as hypothesised by Stewart et al. (2003). Interestingly, these southerly distributed arctic foxes had smaller paws than modern arctic foxes, representing an adaptation to the more southerly local conditions, presumably due to a relative lack of snow fall. This signifies that this non-analogue element of the late Pleistocene, the southern arctic fox population, were different genetically and ecomorphologically from modern counterparts. The range contraction at the end of the Pleistocene represents the extinction of this distinct arctic fox population that had evolved to live in the cold climates at lower latitudes during the later Pleistocene.

Therefore, the individualistic response of species may suggest that a cryptic evolutionary process is disguised in the fossil record. This should act in part as a response to those who have questioned the importance of ice ages to the process of speciation during the Pleistocene (Coope, 1978; Bennett, 1990, 1997; Klicka and Zink, 1997). It has been suggested that climate fluctuations are relatively short and thus cause differently derived populations to be assimilated back into the whole parent population once climate completes a glacial-interglacial cycle. The process evoked would cause stability while the process implicated by the progressive individualistic mixing of species, with extinction, described here, is one of constant ecological and genetic change.

If fossils are as ambiguous taxonomically, as suggested by the taxonomic level to which certain categories of remains are identified or perhaps should be (Moore et al., 1991; Stewart, 2002), it is little wonder that the fossil record has proved relatively unfruitful in documenting evolution in many organisms. The losses of gene pool diversity are only now being revealed by ancient DNA analyses (Barnes et al., 2002; Burger et al., 2004; Shapiro et al., 2004; MacPhee et al., 2005; Orlando et al., 2006; Dalén et al., 2007; Leonard et al, 2007). They confirm that more extinctions at a population level took place across Quaternary climate cycles than has been formerly been recognised. One example of a distinct population loss is that of the wolves of Beringia that went extinct at the end of the Pleistocene, probably following the demise of the megafauna in the area (Leonard et al., 2007). These wolves represent an extinct genotype and ecomorph with adaptations suggesting that they concentrated on hunting and scavenging the animals of the steppe-tundra (Leonard et al., 2007). Such studies imply that gene pools are undergoing selection by environmental change and that this is an evolutionary process that requires more consideration. It is

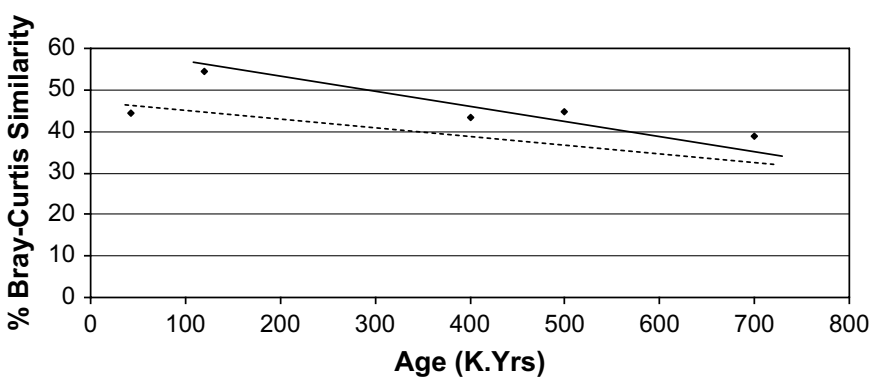

Fig. 3. Hypothesised different, but converging, trend lines of percentage Bray-Curtis similarity indices (to the Holocene mammalian fauna) were available for glacial and interglacial faunas. Key: Solid Line-interglacial trend line; Dashed Line-glacial trend line.

envisaged that the process described will have been progressing throughout geological time, during the Pleistocene certainly, but that because of the use of modern analogues in discerning its existence may be less visible in deeper time. If it is to be recognised at earlier times it will have to be inferred from the recognition of individualistic responses of species to climate and environmental changes rather than in the recognition of nonanalogue communities. The degree to which the modern analogue is used to identify the individualistic response may hamper the recognition of this process in deeper time. A possible example has been described from the Carboniferous where plant communities were shown to be responding individualistically during a time of significant climate change (DiMichele et al., 2001).

\section{Conclusion}

Guthrie (1990a), in his paper on the Late Pleistocene 'faunal revolution', believed that too much focus on the extinctions has obscured the fact that other processes were operating during the time of the Late Pleistocene megafaunal extinctions. Listed amongst the phenomena which took place during the end of the Pleistocene were rapid evolutionary changes, fractionation of biotic communities and enormous reductions in distributional ranges. It can be argued that many, or all, of these changes reflect population size changes. For example geographical distribution reductions often involve a retreat through local population extinctions. Community fractionations are a more complex version of distribution change involving the reorganisation of non-analogue communities and hence are also likely to involve local extinction. Meanwhile rapid evolution often involves extinction followed by immigration of allopatrically distributed, distinct, but congeneric, populations.

Similarly it is important to an understanding of the evolution of organisms during the Quaternary as a whole that other processes were taking place. An analysis of British Pleistocene mammalian faunas has shown that the individualistic response of species to climate change is a progressive phenomenon which causes ecological communities to become increasingly different, compared to the Holocene, with age. This phenomenon is not a simple one as variations exist according to whether faunas lived in interglacial or glacial times. The interglacial faunas become progressively different with age. The single glacial fauna examined in the analysis, from MIS 3, was more different from all the interglacials than they were from each other. It is predicted that the glacial faunas will also become less similar to the Holocene fauna with age on their own trajectory (Fig. 3). Unfortunately this cannot be demonstrated because the history of glacial faunas is much less complete than interglacial ones. It is also possible that the two trajectories will converge back through time (Fig. 3) as the glacially 
adapted taxa are believed to have evolved more recently (Lister, 2004). For example, the mammoth, Mammuthus trogonterii, from the interglacial MIS 17 site of West Runton, is believed to be ancestral to the late Pleistocene woolly mammoth $M$. primigenius of the MIS 3 glacial phase, although the evolution appears to have taken place outside Europe (Lister et al., 2004). Therefore, it is to be expected that glacial and interglacial faunas will be less distinguishable in the past. It is also probable that glacials are likely to be more impoverished in taxonomic diversity with increasing age. The colonisation of colder climates is a more recent phenomenon (Lister, 2004) and the evolution of cold-adapted organisms in these climates, which were more expansive in glacials, must have taken at least one glacial-interglacial cycle to take place.

The pattern described here, with an increase in extirpated and hence non-analogue combinations of organisms with increasing age, is similar to that known for some time where the proportion of extinct taxa increases with age. Indeed they are probably related phenomena as many of the non-analogue elements are likely to be extinct populations, adapted to environments and ecologies that are extinct.

Finally, it seems likely that the progressive process (the individualistic response of species) causing the pattern of increasing ecological difference with age has important implications for other related processes taking place in the Quaternary. The location and nature of refugia for species, the pattern and process of extinction of species and populations of species, and the evolution of the species will be affected by the progressively different, recombining, faunas of the Pleistocene. The individualistic response of species is recognised by most palaeoecologists working in the Quaternary but perhaps its evolutionary implications are not. The full implications of the phenomenon will doubtlessly emerge with time.

\section{Acknowledgements}

Thanks are due to Simon Parfitt, Adrian Lister, Love Dalén, Steve Brooks, G. Hewitt, R. Graham, Deborah Wells and Rudolf Musil for various fruitful conversations about the present, and related, subjects. Simon Parfitt also gave help in checking the mammalian faunal data analysed for factual accuracy. Paul Eggleton helped with the use of BioDiversity Pro, other statistical advice as well as in the interpretation of that analysis. Finally, Tabitha Stewart Stacey was never far from my mind.

\section{Appendix}

British Mammalian faunas from progressively older Quaternary stages expressed as presence-absence data

\begin{tabular}{|c|c|c|c|c|c|c|}
\hline Taxa & Holocene $^{\mathrm{a}}$ & $\begin{array}{l}\text { MIS } 3 \\
(60-25 \mathrm{~K} \mathrm{yrs})^{\mathrm{b}}\end{array}$ & MIS $5 e^{c}$ & $\begin{array}{l}\text { MIS } 11 \\
\text { (Swanscombe, } \\
\text { Barnham and } \\
\text { Beeches Pit) }\end{array}$ & $\begin{array}{l}\text { MIS } 13 \\
{\text { (Boxgrove })^{e}}^{\text {Boxg }}\end{array}$ & $\begin{array}{l}\text { MIS } 17 \\
\text { (West Runton) }^{\mathrm{f}}\end{array}$ \\
\hline Erinaceus sp. and E. europaeus & 1 & 0 & 0 & 0 & 1 & 1 \\
\hline Sorex araneus & 1 & 0 & 1 & 0 & 0 & 0 \\
\hline Sorex minutus & 1 & 0 & 1 & 1 & 1 & 1 \\
\hline Sorex runtonensis & 0 & 0 & 0 & 1 & 1 & 1 \\
\hline Sorex savini & 0 & 0 & 0 & 0 & 1 & 1 \\
\hline Neomys sp. and $N$. fodiens & 1 & 1 & 1 & 1 & 1 & 0 \\
\hline Neomys newtoni & 0 & 0 & 0 & 0 & 0 & 1 \\
\hline Macroneomys brachygnathus & 0 & 0 & 0 & 0 & 0 & 1 \\
\hline Crocidura sp. & 0 & 0 & 0 & 1 & 0 & 0 \\
\hline Talpa europaea & 1 & 0 & 0 & 0 & 1 & 1 \\
\hline Talpa minor & 0 & 0 & 0 & 1 & 1 & 1 \\
\hline Desmana moschata & 0 & 0 & 0 & 1 & 0 & 1 \\
\hline Homo sapiens & 1 & 1 & 0 & 0 & 0 & 0 \\
\hline Homo cf. neanderthalensis & 0 & 1 & 0 & 1 & 0 & 0 \\
\hline Homo cf. heidelbergensis & 0 & 0 & 0 & 0 & 1 & 0 \\
\hline Macaca sylvanus & 0 & 0 & 0 & 1 & 0 & 1 \\
\hline Lepus sp. and Lepus timidus & 1 & 1 & 0 & 0 & 1 & 1 \\
\hline Oryctolagus cuniculus & 0 & 0 & 0 & 1 & 1 & 0 \\
\hline Ochotona pusilla & 0 & 1 & 0 & 0 & 0 & 0 \\
\hline Sciurus sp. and S. vulgaris & 1 & 0 & 0 & 1 & 1 & 0 \\
\hline Citellus sp. & 0 & 1 & 0 & 0 & 0 & 0 \\
\hline Trogontherium cuvieri & 0 & 0 & 0 & 1 & 0 & 1 \\
\hline Castor fiber & 1 & 0 & 1 & 1 & 1 & 1 \\
\hline Cricetus cricetus & 0 & 0 & 0 & 0 & 0 & 1 \\
\hline Cricetulus migratorius & 0 & 0 & 0 & 0 & 0 & 1 \\
\hline Dicrostonyx torquatus & 0 & 1 & 0 & 0 & 0 & 0 \\
\hline Myopus schisticolor & 0 & 0 & 0 & 0 & 1 & 0 \\
\hline Clethrionomys glareolus & 1 & 0 & 1 & 1 & 1 & 1 \\
\hline Pliomys episcopalis & 0 & 0 & 0 & 0 & 1 & 1 \\
\hline Arvicola terrestris terrestris & 1 & 1 & 0 & 0 & 0 & 0 \\
\hline Arvicola terrestris cantiana & 0 & 0 & 1 & 1 & 1 & 0 \\
\hline Mimomys savini & 0 & 0 & 0 & 0 & 0 & 1 \\
\hline Pitymys gregaloides & 0 & 0 & 0 & 0 & 0 & 1 \\
\hline $\begin{array}{l}\text { Microtus (Terricola) subterraneus and } \\
\text { M. cf. subterraneus }\end{array}$ & 0 & 0 & 0 & 1 & 1 & 1 \\
\hline Microtus gregalis & 0 & 1 & 0 & 0 & 1 & 0 \\
\hline Microtus arvalis & 0 & 1 & 0 & 1 & 1 & 0 \\
\hline Microtus agrestis & 1 & 1 & 1 & 1 & 1 & 0 \\
\hline Microtus oeconomus & 0 & 1 & 1 & 1 & 1 & 1 \\
\hline Apodemus flavicollis & 1 & 0 & 0 & 0 & 0 & 0 \\
\hline \multirow[t]{2}{*}{ Apodemus sylvaticus } & 1 & 0 & 1 & 1 & 1 & 1 \\
\hline & & & & & & inued on nex \\
\hline
\end{tabular}


Appendix (continued)

\begin{tabular}{|c|c|c|c|c|c|c|}
\hline Taxa & Holocene $^{\mathrm{a}}$ & $\begin{array}{l}\text { MIS } 3 \\
(60-25 \mathrm{~K} \mathrm{yrs})^{\mathrm{b}}\end{array}$ & MIS $5 e^{c}$ & $\begin{array}{l}\text { MIS } 11 \\
\text { (Swanscombe, } \\
\text { Barnham and } \\
\text { Beeches Pit) }\end{array}$ & $\begin{array}{l}\text { MIS } 13 \\
{\text { (Boxgrove })^{e}}^{\text {Boxg }}\end{array}$ & $\begin{array}{l}\text { MIS } 17 \\
\text { (West Runton) }\end{array}$ \\
\hline Apodemus maastrichtiensis & 0 & 0 & 0 & 1 & 1 & 0 \\
\hline Sicista cf. betulina & 0 & 0 & 0 & 0 & 1 & 0 \\
\hline Eliomys quercinus & 0 & 0 & 0 & 1 & 1 & 0 \\
\hline Muscardinus avellanarius & 1 & 0 & 0 & 0 & 1 & 0 \\
\hline Canis lupus & 1 & 1 & 1 & 1 & 0 & 0 \\
\hline Canis lupus mosbachensis & 0 & 0 & 0 & 0 & 1 & 1 \\
\hline Vulpes vulpes & 1 & 1 & 1 & 0 & 0 & 0 \\
\hline Alopex lagopus & 0 & 1 & 0 & 0 & 0 & 0 \\
\hline Ursus arctos & 1 & 1 & 1 & 0 & 0 & 0 \\
\hline Ursus spelaeus & 0 & 1 & 0 & 1 & 0 & 0 \\
\hline Ursus deningeri & 0 & 0 & 0 & 0 & 1 & 1 \\
\hline Mustela nivalis and $M$. erminea & 1 & 1 & 0 & 0 & 1 & 1 \\
\hline Mustela lutreola & 0 & 0 & 0 & 0 & 1 & 0 \\
\hline Mustela putorius and $M$. cf. putorius & 1 & 1 & 0 & 1 & 0 & 0 \\
\hline Mustela putorius robusta & 0 & 1 & 0 & 0 & 0 & 0 \\
\hline Meles sp. and Meles meles & 1 & 0 & 1 & 0 & 1 & 0 \\
\hline Gulo gulo & 0 & 1 & 0 & 0 & 0 & 0 \\
\hline Martes sp. and M. martes & 1 & 0 & 0 & 1 & 0 & 1 \\
\hline Pannonictis sp. & 0 & 0 & 0 & 0 & 0 & 1 \\
\hline Lutra sp. and L. lutra & 1 & 0 & 0 & 0 & 0 & 1 \\
\hline Crocuta crocuta & 0 & 1 & 1 & 0 & 1 & 1 \\
\hline Panthera leo & 0 & 1 & 1 & 1 & 1 & 0 \\
\hline Panthera cf. gombaszoegensis & 0 & 0 & 0 & 0 & 1 & 1 \\
\hline Felis sylvestris and Felis sp. & 1 & 1 & 1 & 1 & 1 & 1 \\
\hline Lynx lynx & 1 & 0 & 0 & 0 & 0 & 0 \\
\hline Mammuthus primigenius & 0 & 1 & 0 & 0 & 0 & 0 \\
\hline Mammuthus trogontherii & 0 & 0 & 0 & 0 & 0 & 1 \\
\hline Palaeoloxodon antiquus & 0 & 0 & 1 & 1 & 0 & 0 \\
\hline Equus sp. and Equus ferus & 0 & 1 & 0 & 1 & 1 & 1 \\
\hline Equus hydruntinus & 0 & 0 & 0 & 1 & 0 & 0 \\
\hline Stephanorhinus sp. A. & 0 & 0 & 0 & 0 & 1 & 0 \\
\hline Stephanorhinus hundsheimensis & 0 & 0 & 0 & 0 & 1 & 1 \\
\hline Stephanorhinus kirchbirgensis & 0 & 0 & 0 & 1 & 0 & 0 \\
\hline Stephanorhinus hemitoechus & 0 & 0 & 1 & 1 & 0 & 0 \\
\hline Coelodonta antiquitatis & 0 & 1 & 0 & 0 & 0 & 0 \\
\hline Sus scrofa & 1 & 0 & 1 & 1 & 1 & 1 \\
\hline Hippopotamus amphibius & 0 & 0 & 1 & 0 & 0 & 0 \\
\hline Megaloceros giganteus & 0 & 1 & 1 & 1 & 0 & 0 \\
\hline Megaloceros verticornis & 0 & 0 & 0 & 0 & 1 & 1 \\
\hline Megaloceros dawkinsi & 0 & 0 & 0 & 0 & 1 & 0 \\
\hline Megaloceros savini & 0 & 0 & 0 & 0 & 0 & 1 \\
\hline Dama dama & 0 & 0 & 1 & 1 & 1 & 1 \\
\hline Cervus elaphus & 1 & 1 & 1 & 1 & 1 & 1 \\
\hline Capreolus capreolus & 1 & 0 & 0 & 1 & 1 & 1 \\
\hline Alces alces & 1 & 1 & 0 & 0 & 0 & 0 \\
\hline Alces latifrons & 0 & 0 & 0 & 0 & 0 & 1 \\
\hline Rangifer tarandus & 0 & 1 & 0 & 0 & 0 & 0 \\
\hline Bos primigenius & 1 & 1 & 1 & 1 & 0 & 0 \\
\hline Bison priscus & 0 & 1 & 1 & 1 & 1 & 0 \\
\hline Bison schoentensacki & 0 & 0 & 0 & 0 & 0 & 1 \\
\hline Caprinae & 0 & 0 & 0 & 0 & 1 & 0 \\
\hline
\end{tabular}

a Stuart (1995), Lever (1977), Yalden (1999).

b Stewart et al. (2003).

c Stuart (1995), Currant and Jacobi (2001).

d Parfitt (1998).

e Parfitt (1999), Parfitt (pers. comm.).

f Stuart (1988), Preece and Parfitt (2000), Maul and Parfitt (in press).

\section{References}

Alroy, J., 1999. Putting North America's End-Pleistocene megafaunal extinction in context. Large-scale analyses of spatial patterns, extinction rates and size distributions. In: MacPhee, R.D.E. (Ed.), Extinction in Near Time, Causes, Contexts, and Consequences. Kluwer Academic/Plenum Publishers, New York, pp. 105-143.

Anderson, L.L., Sheng Hu, F., Nelson, D.M., Petit, R.J., Paige, K.N., 2006. Ice-age endurance: DNA evidence of a white spruce refugium in Alaska. Proceedings of the National Academy of Science USA 13, 12447-12450.

Barnes, I., Matheus, P., Shapiro, B., Jensen, D., Cooper, A., 2002. Dynamics of Pleistocene population extinctions in Beringian brown bears. Science 295, 2267-2270.

Bates, M.R., Bates, C.R., Gibbard, P.L., Macphail, R.I., Owen, F.J., Parfitt, S.A., Preece, R.C., Roberts, M.B., Robinson, J.E., Whittaker, J.E., Wilkinson, K.N., 2000.

Late Middle Pleistocene deposits at Norton Farm on the West Sussex coastal plain, southern England. Journal of Quaternary Science 15 (1), 61-89.

Bell, G.F., 1969. The occurrence of southern, steppe and halophytic elements in the Weichselian (Last Glacial) floras of southern Britain. New Phytologist 68, 913-922.

Bennett, K.D., 1990. Milankovitch cycles and their effects on species in ecological and evolutionary time. Paleobiology 16, 11-21.

Bennett, K.D., 1997. Evolution and Ecology: The Pace of Life. Cambridge Studies in Ecology. Cambridge University Press, Cambridge.

Bennett, K.D., Provan, J., 2008. What do we mean by 'refugia'? Quaternary Science Reviews 27. doi: 10.1016/j.quascirev.2008.08.019.

Bramwell, D., 1984. The birds of Britain: when did they arrive? In: Gilbertson, D.D., Jenkinson, R.D.S. (Eds.), In the Shadow of Extinction: A Quaternary Archaeology and Palaeoecology of the LakeFissures and Smaller Caves at Cresswell Crags SSSI. University of Sheffield, John Collis Publisher, Sheffield. 
Brasso, R.L., Emslie, S.D., 2006. Two new Late Pleistocene Avifaunas from New Mexico. The Condor 108, 721-730.

Burger, J., Rosendahl, W., Loreille, O., Hemmer, H., Eriksson, T., Götherström, A. Hiller, J., Collins, M.J., Wess, T., Alt, K.W., 2004. Molecular phylogeny of the extinct cave lion Panthera leo spelaea. Molecular Phylogenetics and Evolution 30, 841-849.

Clark, J.S., Fastie, C., Hurtt, G., Jackson, S.T., Johnson, C., King, G.A., Lewis, M., Lynch, J., Pacala, S., Prentice, C., Schupp, E.W., Webb III, T., Wycko, P., 1998. Reid's paradox of rapid plant migration. BioScience 48, 13-24.

Clements, F.E., 1904. Plant Succession: An Analysis of the Development of Vegetation. Carnegie Institute, Washington.

Coope, G.R., 1978. Constancy of species versus inconstancy of Quaternary environments. In: Mound, L.A., Waloff, N. (Eds.), Diversity of Insect Faunas. Blackwell Science, London, pp. 176-187.

Coope, G.R., 2000. Middle Devensian (Weichselian) coleopteran assemblages from Earith, Cambridge (UK) and their bearing on the interpretation of 'Full glacial' floras and faunas. Journal of Quaternary Science 15 (8), 779-788.

Coope, G.R., Angus, R.B., 1975. An ecological study of a temperate interlude in the middle of the last glaciation, based on fossil Coleoptera from Isleworth, Middlesex. Journal of Animal Ecology 44, 365-391.

Currant, A.P., Jacobi, R.M., 2001. A formal biostratigraphy for the Late Pleistocene of Britain. Quaternary Science Reviews 20 (16-17), 1707-1716.

Dalén, L., Fuglei, E., Hersteinsson, P., Kapel, C.M.O., Roth, J.D., Samelius, G. Tannerfeld, M., Angerbjörn, A., 2005. Population history and genetic structure of a circumpolar species: the arctic fox. Biological Journal of the Linnean Society $84,79-89$.

Dalén, L., Nyström, V., Valdiosera, C., Germonpré, M., Sablin, M., Turner, E. Angerbjörn, A., Arsuaga, J.L., Götherström, A., 2007. Genetic contribution of Arctic population in the South: Post recolonisation of the Arctic fox in Europe. Proceedings of the National Academy of Science USA 104 (16), 6726-6729.

DiMichele, W.A., Pfefferkorn, H.W., Gastaldo, R.A., 2001. Response of Late Carboniferous and Early Permian plant communities to climate change. Annual Review of Earth Planetary Sciences 29, 461-487.

Emslie, S.D., 1986. The late Pleistocene (Rancholabrean) avifauna of Little Box Elder Cave. Wyoming. Contributions to Geology (University of Wyoming)23(2), 63-82

Faunmap Working Group, 1996. Spacial response of mammals to Late Quateranary environmental fluctuations. Science 272, 1601-1606.

Fedorov, V.B., Stenseth, N.C., 2002. Multiple glacial refugia in the North American Arctic: inference from phylogeography of the collared lemming (Dicrostonyx groenlandicus). Proceedings of the Royal Society B 269, 2071-2077.

Gascoyne, M., Currant, A.P., Lord, T., 1981. Ipswichian fauna of Victoria Cave and the marine palaeoclimate record. Nature 294, 652-654.

Gasse, F., Barker, P., Gell, P.A., Fritz, S.C., Chalié, F., 1997. Diatom-inferred salinity in palaeolakes: an indirect tracer of climate change. Quaternary Science Reviews $16,547-563$.

Gilmour, M., Currant, A., Jacobi, R., Stringer, C., 2007. Recent TIMS dating results from British Late Pleistocene vertebrate faunal localities: context and interpretation. Journal of Quaternary Science 22 (8), 793-800.

Gleason, H.A., 1926. The individualistic concept of the plant association. Bulletin of the Torrey Botanical Club 53,1-20.

Graham, R.W., 1985a. Response of mammalian communities to environmenta changes during the Late Quaternary. In: Diamond, J., Case, T.J. (Eds.), Community Ecology. Harper and Row Publishers, New York, pp. 300-313.

Graham, R.W., 1985b. Diversity and community structure of the late Pleistocene mammal fauna of North America. Acta Zoologica Fennica 170, 181-192.

Graham, R.W., 1986. Response of mammalian communities to environmental changes during the late Quaternary. In: Diamond, J., Case, T.J. (Eds.), Community Ecology. Harper and Row, New York, pp. 300-313.

Graham, R.W., 2006. Fallacies of the disharmonious index and relevance of Quaternary non-analogue mammal faunas for future environment change. In Biotic Response to Global Environmental Change: Analogs for the Future of Life on Earth, Philadelphia Annual Meeting (22-25 October 2006). Geologica Society of America Abstracts with Programs, 38, p. 118 (7).

Graham, R.W., Lundelius Jr., E.L., 1984. Coevolutionary disequilibrium and Pleistocene extinctions. In: Martin, P.S., Klein, R.G. (Eds.), Quaternary Extinctions-A Prehistoric Revolution. The University of Arizona Press, Tucson, pp. 149-223.

Graham, R.W., Grimm, E.C., 1990. Effects of global climate change on the patterns of terrestrial biological communities. Trends in Ecology and Evolution 5 (9), 289-292.

Guthrie, R.D., 1990. Late Pleistocene faunal revolution-a new perspective on the extinction debate. In: Agenbroad, L.D., Mead, J.I., Nelson, L.W. (Eds.), Megafauna and Man: Discovery of America's Heartland. North Arizona Press, Flagstaff, pp. $42-53$.

Guthrie, R.D., 1990. Frozen Fauna of the Mammoth Steppe: the Story of Blue Babe. The University of Chicago Press, London.

Harmer, F.W., 1900. The Pliocene deposits of the East of England-_Part II: The crag of Essex (Waltonian) and its relation to that of Suffolk and Norfolk. Quarterly Journal of the Geological Society of London 56, 705-738.

Harmer, F.W., 1900b. On a proposed new classification of the Pliocene deposits of the East of England. Report of the British Association for the Advancement of Science, 751-753 (for 1899).

Head, M.J., 1998. Marine environmental change in the Pliocene and early Pleistocene of eastern England: the dinoflagellate evidence reviewed. Mededelingen Nederlands Instituut voor Toegepaste Geowetenschappen TNO 60, 199-226.

Hengeveld, R., 1994. Biogeographical Ecology. Journal of Biogeography 21, 341-351.
Hewitt, G., 1996. Some genetic consequences of ice ages, and their role in divergence and speciation. Biological Journal of the Linnean Society 58, 247-276.

Hewitt, G., 2000. The genetic legacy of the Quaternary ice ages. Nature 405, 907-913.

Hewitt, G.M., 2001. Speciation, hybrid zones and phylogeography-or seeing genes in space and time. Molecular Ecology 10, 537-549.

Holder, K., Montgomerie, R., Friesen, V.L., 1999. A test of the glacial refugium hypothesis using patterns of mitochondrial and nuclear DNA variation in rock ptarmigan (Lagopus mutus). Evolution 53, 1936-1950.

Huntley, B., 1990. European post-glacial forests: compositional changes in response to climatic change. Journal of Vegetation Science 1, 507-518.

Huntley, B., 1991. How plants respond to climate change: Migration rates, individualism and the consequences for plant communities. Annals of Botany 67 (Supplement 1), 15-22.

Jablonski, D., Sepkoski Jr., J.J., 1996. Paleobiology, community ecology and scales of ecological pattern. Ecology 77 (5), 1367-1378.

Kerney, M.P., 1963. Late-glacial deposits on the chalk of South-East England. Philosophical Transactions of the Royal Society (London) Series B 246 (730), 203-254.

Kitchener, A., Yalden, D.W., 2008. History of the fauna. Pp. 17-31. In: Harris, S., Yalden, D.W. (Eds.), Mammals of the British Isles: Handbook, fourth ed. The Mammal Society, Southampton.

Klicka, J., Zink, R.M., 1997. The importance of recent Ice Ages in Speciation: A failed paradigm. Science 277, 1666-1669.

Kullman, L., 1998. Non-analogous tree flora in the Scandes Mountains, Sweden, during the early Holocene-macrofossil evidence of rapid geographic spread and response to palaeoclimate. Boreas 27, 153-161.

Kullman, L., 2002. Boreal tree taxa in the central Scandes during the Late-Glacial: implications for Late-Quaternary forest history. Journal of Biogeography 29 (9), $1117-1124$

Leonard, J.A., Vilá, C., Fox-Dobbs, K., Koch, P.L., Wayne, R.K., Van Valkenberg, B., 2007. Megafaunal extinctions and the disappearance of a specialized wolf ecomorph. Current Biology 17, 1146-1150.

Lever, C., 1977. The Naturalised Animals of the British Isles. Granada Publishing Limited, London.

Lister, A.M. 2004. The impact of Quaternary Ice Ages on mammalian evolution. In: Willis, K.J., Bennett, K.D., Walker, D. (Eds.), The Evolutionary Legacy of the Ice Ages. Philosophical Transactions of the Royal Society, Biological Sciences, 359, pp. 221-241 (1442).

Lister, A.M., Sher, A.V., van Essen, V., Wei, G., 2004. The pattern and process of mammoth evolution in Eurasia. Quaternary International 126-128, 49-64.

Loehr, J., Worley, K., Grapputo, A., Carey, J., Veitch, A., Coltman, D.W., 2005. Evidence for cryptic glacial refugia from North American mountain sheep mitochondrial DNA. Journal of Evolutionary Biology 19 (2), 419-430.

MacPhee, R.D.E., Tikhonov, A.N., Mol, D., Greenwood, A.D., 2005. Late Quaternary loss of genetic diversity in muskox (Ovibos). BMC Evolutionary Biology, doi:10.1186/1471-2148-5-49.

Markova, A.K., Simakova, A.N., Puzachenko, A.Y., Kitaev, L.M., 2002. Environments of the Russian Plain during the Middle Valdai Briansk Interstade (33,000-24,000 yr B.P.) indicated by fossil mammals and plants. Quaternary Research 57, 391-400.

Maul L.C., Parfitt, S.A., in press. Morphometric data and taxonomic reappraisal of micromammals from the type Cromerian at West Runton, Norfolk, UK, and their biostratigraphic significance. Quaternary International.

Moore, P.D., Webb, J.A., Collinson, M.E., 1991. An Illustrated Guide to Pollen Analysis, second ed. Hodder and Stoughton, Kent.

Mourer-Chauviré, C., 1979. Les Oiseaux de la fin des temps glaciaires en France. La disparition des espèces froides. In: de Sonneville-Bordes, D. (Ed.), Colloques Internationaux C.N.R.S. No. 271.

Musil, R., 1985. Paleobiogeography of terrestrial communities in Europe during the Last Glacial. Acta Musei Nationalis Pragae XLI B, 1-83.

Orlando, L., Darlu, P., Toussaint, D., Bonjean, D., Otte, M., Hänni, C., 2006. Revisiting Neanderthal diversity with a 100,000 year old mtDNA sequence. Current Biology 16, 400-401.

Park, L.E., Downing, K.F., 2001. Paleoecology of an exceptionally preserved arthropod fauna from lake deposits of the Miocene Barstow Formation, Southern California, USA. Palaios 16 (2), 175-184.

Parfitt, S.A., 1998. The interglacial mammalian fauna from Barnham. In: Ashton, N.M., Lewis, S.G., Parfitt, S. (Eds.), Excavations at the Lower Palaeolithic Site at Barnham, 1989-94. British Museum Press, London, pp. 111-147.

Parfitt, S.A., 1999. Mammalia. In: Roberts, M.B., Parfitt, S.A. (Eds.), The Middle Pleistocene Site at ARC Eartham Quarry, Boxgrove, West Sussex, U.K. English Heritage Monograph Series 16, London, pp. 197-290.

Preece, R.C., Bridgland, D.R. (Eds.), 1998. Late Quaternary Environmental Change in North-West Europe: Excavations at Holywell Coombe, South-East England. Chapman and Hall, London.

Preece, R.C., Parfitt, S.A., 2000. The Cromer Forest-Bed Formation: new thoughts on an old problem. In: Lewis, S.G., Whiteman, C.A., Preece, R.C. (Eds.), The Quaternary of Norfolk and Suffolk. Field Guide. Quaternary Research Association, London.

Preece, R.C., Bidgland, D.R., Lewis, S.G., Parfitt, S.A., Griffiths, H.I., 2000. Beeches Pit, West stow, Suffolk (TL 798719). In: Lewis, S.G., Whiteman, C.A., Preece, R.C. (Eds.), The Quaternary of Norfolk and Suffolk Field Guide. Quaternary Research Association, London, pp. 1-27.

Preece, R.C., Parfitt, S.A., Bridgland, D.R., Lewis, S.G., Rowe, P.J., Atkinson, T.C., Candy, I., Debenham, N.C., Penkman, K.E.H., Rhodes, E.J., Schwenninger, J.-L., Griffiths, H.I., Wittaker, J.E., Gleede-Owen, C., 2007. Terrestrial environments during MIS 11: evidence from the Palaeolithic site at West Stow, Suffolk. UK. Quaternary Science Reviews 26 (9-10), 1236-1300. 
Prentice, I.C., 1986. Vegetation response to past climate changes. Vegetatio 67, 131-141.

Pruett, C.L., Winker, K., 2005. Biological impacts of climatic change on a Beringian endemic: cryptic refugia in the establishment and differentiation of the rock sandpiper (Calidris ptilocnemis). Climatic Change 68, 219-240.

Roberts, M.B., Parfitt, S.A., 1999. The Middle Pleistocene Site at ARC Eartham Quarry, Boxgrove, West Sussex, U.K. English Heritage Monograph Series 16 London.

Roy, K., Jablonski, D., Valantine, J.W., 1995. Thermally anomalous assemblages revisited: patterns in the extraprovincial latitudinal range shift of Pleistocene marine mollusks. Geology 23 (12), 1071-1074.

Sanfilippo, R., 1998. Spirorbid polychaetes as Boreal guests in the Mediterranean Pleistocene. Rivista Italiano di Paleontologia e Stratigraphia 104 (2), 279-286.

Schreve, D.C., 2001. Differentiation of the British late Middle Pleistocene interglacials: the evidence from mammalian biostratigraphy. Quaternary Science Reviews 20 (16-17), 1693-1705.

Shapiro, E., Drummond, A.J., Rambaut, A., Wilson, M.C., Matheus, P.E., Sher, A.V., Pybus, O.G., Gilbert, M.T.P., Barnes, I., Binladen, J., Willerslev, E., Hansen, A.J., Baryshnikov, G.F., Burns, J.A., Davydov, S., Driver, J.C., Froese, D.G., Harington, C.R., Keddie, G., Kosintsev, P., Kunz, M.L., Martin, L.D., Stephenson, R.O., Storer, J., Tedford, R., Zimov, S., Cooper, A., 2004. Rise and fall of the Beringian steppe Bison. Science 306, 1561-1565.

Smith, R.L., Smith, T.H., 1998. Elements of Ecology, fourth ed. The Benjamin/Cummings Publishing Company, California.

Stafford Jr., T.M., Semken Jr., H.A., Graham, R.W., Klipel, W.F., Markova, A., Smirnov, N., Southon, J., 1999. First accelerator mass spectrometry ${ }^{14} \mathrm{C}$ dates documenting contemporaneity of non-analogue species in late Pleistocene mammal communities. Geology 27 (10), 903-906.

Stewart, J.R., 1999. Intraspecific variation in modern and Quaternary European Lagopus. Smithsonian Contributions to Paleobiology 89, 159-168.

Stewart, J.R., 2002. The evidence for the timing of speciation of modern continental birds and the taxonomic ambiguity of the Quaternary fossil record. In: Zhou, Z., Zhang, F. (Eds.), Proceedings of the 5th Symposium of the Society of Avian Paleontology and Evolution. China Science Press, Beijing, pp. 261-282.

Stewart, J.R., 2005. The ecology and adaptation of Neanderthals during the non-analogue environment of Oxygen Isotope Stage 3. Quaternary International 137, 35-46.

Stewart, J.R., Dalén, L., 2008. Is the glacial refugium concept relevant for northern species? Climatic Change 86, 19-22.

Stewart, J.R., Lister, A.M., 2001. Cryptic northern refugia and the origins of modern biota. Trends in Ecology and Evolution 16 (11), 608-613.

Stewart, J.R., van Kolfschoten, M., Markova, A., Musil, R., 2001. The StageThree Project Mammalian database. http://www.esc.esc.cam.ac.uk/oistage3/Details/ Homepage.html

Stewart, J.R., van Kolfschoten, M., Markova, A., Musil, R., 2003. The Mammalian Faunas of Europe during Oxygen Isotope Stage Three. In: van Andel, T.H.,
Davies, S.W. (Eds.), Neanderthals and Modern Humans in the European Landscape during the Last Glaciation60,000 to 20,000 years ago: Archaeological Results of the Stage 3 Project. MacDonald Institute Monograph Series, Cambridge, pp. 103-130.

Stuart, A.J., 1988. Vertebrate fauna. In: Gibbard, P.L., Zalasiewicz, J.A. (Eds.), PlioceneMiddle Pleistocene of East Anglia. Field Guide. Quaternary Research Association, Cambridge, pp. 152-157.

Stuart, A.J., 1995. Insularity and Quaternary vertebrate faunas in Britain and Ireland. In: Preece, R.C. (Ed.), Island Britain: a Quaternary Perspective. Geological Society Special Publication No. 96, pp. 111-125.

Sullivan, J., Arellano, E., Rogers, D.S., 2000. Comparative phylogeography of Mesoamerican highland rodents: concerted versus independent response to past climatic fluctuations. The American Naturalist 155 (6), 755-768.

Sutcliffe, A.J., Kowalski, K., 1976. Pleistocene rodents of the British Isles. Bulletin of the British Museum (Natural History). Geology 27 (2), 33-147.

Taberlet, P., Fumagalli, L., Wust-Saucy, A., Cosson, J., 1998. Comparative phylogeography and postglacial colonization routes in Europe. Molecular Ecology 8, 1923-1934.

Tankersley, K.B., 1999. Sheriden: a stratified Pleistocene-Holocene cave site in the Great Lakes Region of North America. In: Driver, J.C. (Ed.), Zooarchaeology of the Pleistocene/Holocene BoundaryProceedings of a Symposium Held at the International Council for Archaeozoology (ICAZ) Victoria, British Columbia Canada. August 1998. BAR International Series 800, pp. 67-75.

Tremblay, N.O., Schoen, D.J., 1999. Molecular phylogeography of Dryas integrifolia: glacial refugia and postglacial recolonization. Molecular Ecology 8 1187-1198.

Tyrberg, T., 1991. Arctic, Montane and Steppe birds as Glacial relicts in West Palearctic. Ornithologische Verhandlungen 25, 29-49.

Tyrberg, T., 1995. Palaeobiogeography of the genus Lagopus in the West Palearctic. Courier Forschungsinstitut Senckenberg 181, 275-291.

Tzedakis, P.C., Bennett, K.D., 1996. Interglacial vegetation succession: A view from southern Europe. Quaternary Science Reviews 14 (10), 967-982.

Webb, T., 1986. Is vegetation in equilibrium with climate? How to interpret late Quaternary pollen data. Vegetatio 67, 75-91.

West, R.G., 1970. Pollen zones in the Pleistocene of Great Britain and their correlation. New Phytologist 69 (4), 1179-1183.

West, R.G., 1980. Pleistocene forest history in East Anglia. New Phytologist 85, 571-622.

Williams, J.W., Shuman, B.N., Webb III, T., 2001. Dissimilarity analyses of LateQuarternary vegetation and climate in eastern North America. Ecology 82 (12), 3346-3362.

Williams, J.W., Jackson, S.T., 2007. Novel climates, no-analog communities, and ecological surprises Frontiers in Ecology and the Environment 5 (9), 475-482.

Yalden, D.W., 1999. The History of British mammals. T. \& AD Poyser, London. 